\title{
$O$ resgate do que se desmancha: a cartografia da pacificação da Balaiada
}

\author{
Adriana Barreto de Souza
}

\begin{abstract}
A utilização de termos espaciais tinha um quê de antihistória (...) Se alguém falasse em termos de espaço, é porque era contra o tempo. Eles não compreendiam que (...) é efetivamente de guerra, de administração, de implantação de gestão de um poder que se trata em tais expressões.
\end{abstract}

(Michel Foucault)

As forças destinadas a reprimir a Balaiada deixaram o porto do Rio de Janeiro em direção ao Maranhão mais de um ano após a eclosão do movimento, no dia 22 de dezembro de 1839. A morosidade da ação do governo devia-se em parte às resistências do Parlamento para votar medidas de força contra as províncias. A Regência Araújo Lima, a primeira dos conservadores, apesar de ter maioria nas duas câmaras, enfrentava dificuldades para vencer uma certa "cultura da liberdade", cultivada como resistência ao poder central durante os longos anos de vida colonial. Assim, para fazer frente aos receios de se armar o Estado, o governo empenhou-se na articulação de um discurso forte, que revolvia um grande medo dessa elite política, o da fragmentação territorial. ${ }^{1}$

O poeta conservador Domingos José Gonçalves de Magalhães, que embarcou para o Maranhão como secretário do coronel comandante das forças de repressão, Luiz Alves de Lima e Silva (futuro duque de Caxias), expressou sua consternação diante de tantas "lutas, tropeços e fadigas", comparando o Império de então a um corpo seriamente comprometido por uma enorme chaga. ${ }^{2}$ De fato, os anos regenciais foram difíceis. Entre 1831 e 1840, dezenove rebeliōes eclodiram em todo o Império. ${ }^{3} \mathrm{Em}$ 1840, ano em que o poeta chegou a São Luís na expedição militar do coronel Lima, uma província vizinha ao Maranhão, o Pará, e uma outra, de fronteira delicada, o Rio Grande do Sul, também estavam convulsionadas. Ambas em armas há cinco anos, desde 1835. 
A intenção desse artigo é descrever a atuação e as estratégias empregadas pelas forças imperiais na última fase da repressão à Balaiada (18401841), a fim de mostrar como o discurso da ordem inscreveu-se no território do Maranhão. O conceito de território agrega processos próprios do campo da política. Ele envolve a relação de uma sociedade com um espaço determinado e, nesse sentido, é a apropriação que qualifica uma porção de terra: usos, conflitos, negociações, hegemonias e violências sustentadas por ações e projetos políticos específicos. ${ }^{4}$ Daí a idéia de cartografia da pacificação. Ao enviar tropas para o Maranhão, o interesse da regência era criar (e recriar onde fosse interessante) redes de dominação e circuitos de exploração econômica que garantissem a submissão desse território aos princípios políticos conservadores.

\section{O Rio de Janeiro, o coronel e o poeta}

Se Gonçalves de Magalhães via as rebeliōes regenciais comprometendo o corpo do Império, é preciso lembrar que essa sensação de que suas estruturas física, política e social se dissolviam já vinha sendo experimentada por grande parte da elite desde a abdicação do primeiro Imperador, em abril de 1831. Ainda nesse ano, diante das rusgas e levantes militares que tomavam de assalto as ruas do Rio de Janeiro, o então ministro da Justiça Diogo Feijó expressava sentimento semelhante, afirmando ter a sensação de que um "abismo horroroso" se abria a seus pés. ${ }^{5}$ A definição de Império como "resgate de algo que se desmancha" e "promessa de estabilidade no futuro" é, nesse sentido, bastante precisa. ${ }^{6}$ Consolidar o Império do Brasil era antes de tudo assegurar a unidade territorial. Foi a partir dessa discussão, de como reconstruir a ordem, que liberais e conservadores se distinguiram politicamente.

Apesar das discordâncias, homens como Honório, Vasconcelos e Araújo Lima, em 1831, estiveram unidos a Diogo Feijó na defesa da Regência e na tarefa de conter a agitação das ruas. Essa unidade, mesmo frágil, era mantida pelo receio de um possível retorno de d. Pedro I e de uma completa subversão das hierarquias sociais. Em 1834, o primeiro imperador morreu em Portugal. No ano seguinte, eclodiram a Cabanagem, no Pará, e a Farroupilha, no Rio Grande do Sul. Esta surpreendia por ser uma revolta exclusivamente de proprietários. A primeira desse tipo, envolven- 
do parte da elite, tinha sido a dos cabanos de Pernambuco e Alagoas. Ela aproximou, de forma assustadora, pequenos proprietários, camponeses, índios e escravos. ${ }^{7}$ Unindo-se ou não ao povo e à plebe, os levantes de proprietários comprometiam os liberais de 1831, sobretudo Diogo Feijó, então regente e um importante nome na defesa da autonomia provincial.

O bloco monarquista tradicional, aglutinado em torno de Honório Hermeto Carneiro Leão, não mais ameaçado pela volta de d. Pedro, abriu franca oposição ao regente. ${ }^{8}$ Valendo-se do espraiamento das rebeliōes, logo exigiu mais força para o Estado. A questão era de arranjo institucional. A política descentralizadora liberal, implementada após o 7 de abril como uma espécie de "guerrilha burocrática" contra as arbitrariedades de d. Pedro, ${ }^{9}$ deixava o governo agora refém das facçōes provinciais. Para piorar, em 1836 os farrapos criaram a República do Piratini. Aparecia assim um novo medo - temia-se a fragmentação do Império. Pela exploração desses dois grandes medos - da "anarquia" e da fragmentação territorial -, a ala monarquista fundamentou o que ficaria conhecido como discurso da ordem, uma política conservadora e centralizadora.

Em 18 de setembro de 1837, Feijó renunciou. No dia seguinte, o ministro do Império, Araújo Lima, assumiu a Regência e o gabinete organizado era fiel à nova política. A figura de proa desse gabinete, acumulando os ministérios da Justiça e do Império, era Bernardo Pereira de Vasconcelos, que até 1835 tinha participado ativamente, ao lado de Feijó, da montagem da tal "guerrilha burocrática". Como liberal, havia defendido a criação dos juízes de paz, propôs o fim do Desembargo do Paço e sua substituição pelo Tribunal Superior de Justiça e participou ainda da elaboração dos projetos do Código Criminal e do Ato Adicional. ${ }^{10}$ No entanto, como ele mesmo afirmaria, essas idéias eram parte de seu passado - havia sido liberal.

Vasconcelos agora era conservador e, durante o tempo que esteve à frente do gabinete, demonstrou especial capacidade para treinar jovens nos ideais conservadores. Opondo-se à tradição, três ministros do novo gabinete não tinham mais de 35 anos de idade. Mas esses jovens, todos diplomados, recém-egressos de universidades européias e com grandes possibilidades de fazer uma promissora carreira no serviço público, tinham um enorme interesse no projeto de Vasconcelos. Isso porque ele propunha um regresso, a recentralização do poder sob controle do gover- 
no nacional. Considerava que o único modo de frear a "revolução" era pela correção de supostas imprudências dos textos liberais. A proposta de reforma no Código de Processo Criminal é um bom exemplo do que foram essas correções. Ela removia os poderes policiais atribuídos, por ele próprio, anos antes, aos juízes de paz e os transferia para funcionários subordinados a chefes de polícia, que, por sua vez, eram selecionados pelo poder central entre os magistrados profissionais. ${ }^{11}$

Luiz Alves de Lima - como o oficial assinava seu nome - e Domingos José Gonçalves de Magalhães faziam parte dessa nova e promissora geração. Em 1839, o coronel Lima contava 36 anos e o poeta era um jovem de 28 anos de idade. Recém-chegado ao Brasil, após anos de estudos na França, Gonçalves de Magalhães ainda se ambientava no Brasil. Mas o coronel Lima já vinha sendo devidamente observado e apoiado por Bernardo Pereira de Vasconcelos desde pelo menos setembro de 1837.

No seu primeiro relatório como ministro da Justiça, em 1838, Vasconcelos elogiou publicamente, para toda a Câmara, a eficiência da Guarda de Municipais Permanentes em missão na província de Santa Catarina. Afirmou, que o bom resultado alcançado pela guarda se devia a seu incansável chefe, o "sr. Luiz Alves de Lima". ${ }^{12}$ Logo no início desse mesmo ano, em fevereiro, através de correspondências oficiais, já tecia vários elogios ao oficial-comandante. Parabenizava-o, sobretudo, pelo asseio e disciplina com que os Permanentes se apresentavam para os exercícios de manobra e fogo no Campo da Honra, um deles assistido pelo regente e por Sua Majestade. ${ }^{13}$ Esses elogios resultaram em duas nomeaçóes: uma em março de 1839, para acompanhar o ministro Sebastião do Rego Barros em expedição militar ao sul, a outra em dezembro, para comandar a repressão aos balaios no Maranhão.

Aderindo à política conservadora, Luiz Alves de Lima seguia para o Maranhão acumulando os cargos de presidente e comandante de armas da província do Maranhão. Ou seja, embarcava investido de amplos poderes militares e civis. Essa era mais uma estratégia de força criada pelo primeiro imperador que os regressistas recuperavam.

Domingos José Gonçalves de Magalhães, o jovem poeta, era um “amigo leal” e, ao que tudo indica, foi escolhido pelo próprio coronel Lima para secretariá-lo durante a campanha. Gonçalves de Magalhães estava 
no Brasil há apenas dois anos e meio, após ter viajado pela Europa e freqüentado, por vários anos, aulas de economia política, direito e química em Paris, diplomando-se em medicina. Seu currículo era admirável. Aos 28 anos, era membro do Instituto Histórico da França, do Instituto Histórico e Geográfico Brasileiro, havia integrado a Legação de Negócios na Corte Francesa e já era conhecido por seus Suspiros Poéticos e Saudades. Regressou ao Brasil em 1837 e, desde então, vinha se dedicando a projetos culturais e a suas aulas no colégio Pedro II. ${ }^{14}$

A função dos secretários de governo, segundo insinuação do próprio Gonçalves de Magalhães, era redigir textos oficiais e auxiliar o presidente na administração da província. ${ }^{15}$ Mas, nesse caso, o secretário era também um homem de letras, e tinha seus próprios interesses. Desde 1836, vinha se dedicando a estudos sobre a origem da literatura nacional, sobre sua singularidade e marcas inconfundíveis de brasilidade. ${ }^{16}$ Ainda que não seja objetivo desse artigo discutir o livro "A revolução na província do Maranhão desde 1839 a 1840 ” - até porque para realizar uma boa análise deste teríamos, como afirma Luiz Felipe de Alencastro, de pensar Gonçalves de Magalhães também como autor de poemas, peças de teatro e ensaio literário - vale destacar que o envolvimento do autor na política deve-se a uma concepção de literatura que engloba todas as formas de expressão do "espírito nacional". ${ }^{17}$ Daí seu interesse pela secretaria de governo. Ao chegar ao Maranhão, aproveitou o cargo para pesquisar e conhecer melhor "nossos costumes e naturais tendências". O livro resulta dessas pesquisas.

À exceção do primeiro capítulo, todo o livro foi escrito durante o tempo em que Gonçalves de Magalhães esteve na província. Nele aborda, inclusive, fatos ocorridos antes de sua chegada a São Luís. Para isso, pesquisou em importantes jornais locais, como a Chrônica Maranhense, de João Francisco Lisboa. Estava convencido de que só pelo estudo do passado "de nossas desordens" seria possível coligir uma "lição histórica". Essa lição guardaria uma vinculação estreita com o presente: possibilitaria uma intervenção na realidade e, desse modo, poderia evitar a perda de "fé no futuro". ${ }^{18}$ Foi com esse espírito, quase missionário, que Gonçalves de Magalhães participou, lado a lado com o coronel Lima, da repressão aos balaios. O secretário do governo pensava a rebelião e os maranhenses e, a partir dessa reflexão, não só orientava a repressão, como incorporava essas novas terras - enquanto território submetido - no Império do Brasil. 


\section{Cabanos e bentevis}

As forças da repressão só chegaram ao Maranhão no dia 4 de fevereiro. Na manhã do dia 5, ao longo do cais do porto de Santa Maria, parte da tropa local, enfileirada, em uniforme de gala, recepcionava o novo presidente e comandante da província. Altas autoridades de ambos os partidos, liberal e conservador, dignitários do clero e gente do povo afluíram para o local. ${ }^{19} \mathrm{O}$ espírito conciliatório era sinal de cansaço. Após mais de um ano de rebelião, a economia da província estava falida e sua estrutura escravocrata, com sérias fissuras. Esse quadro favorecia Luiz Alves. Liberais e conservadores - bentevis e cabanos, respectivamente -, após tudo comprometerem, superavam suas divergências para reprimir o movimento. Luiz Alves era a esperança desses homens, dispostos a colaborar.

Mas nem sempre tinha sido assim. ${ }^{20}$ Os conflitos na província se deram em dois níveis. Um deles envolvia disputas partidárias. Nas eleições de 1836, os bentevis, há anos no governo, foram derrotados. Desconfiava-se de que os cabanos, com maioria na Assembléia, influenciaram o resultado da votação. A recorrência a práticas violentas criou uma tensão extra. O clima piorou com a aprovação, pelo legislativo provincial, em 1838, da lei dos prefeitos e da lei dos Guardas Nacionais. Através delas, a organização administrativa da província foi totalmente alterada. Em escala decrescente, a nova ordem instituía, para o governo de cada comarca, um prefeito; para o governo de cada termo, um subprefeito; e, nos distritos, tantos comissários de polícia quanto o prefeito, ouvindo o subprefeito, julgasse necessário. A todos esses funcionários foram atribuídos amplos poderes, retirados dos juízes de paz eleitos localmente. O executivo municipal ficava assim sob domínio dos prefeitos e, como esses eram nomeados pelo presidente da província, o sistema eliminava a oposição. A capacidade de controle se tornou ainda maior quando os prefeitos passaram a nomear os comandantes da Guarda Nacional. Essas leis mostram, com nitidez, o que era o rearranjo institucional proposto pelos conservadores em plano nacional e como esse arranjo interferia na política regional, provocando cisões e conflitos intra-elite. ${ }^{21}$

Outro nível de conflitos envolvia insatisfações sociais, de mestiços e negros. A população de escravos da província nas primeiras décadas do século XIX era grande. Há uma estimativa de que, em 1822, ano da in- 
dependência, a proporção fosse de dois escravos para um livre. ${ }^{22}$ Centenas deles, fugindo dos maltratos de seus senhores, aquilombavam-se nas matas, de onde saíam para surtidas rápidas e violentas sobre propriedades agrárias. Aos negros, recorria-se com desconfiança para decidir conflitos políticos. Mas os proprietários não tinham o mesmo cuidado com os mestiços. Vaqueiros, barqueiros, trabalhadores domésticos, o grupo formava o contingente em armas de todos os conflitos da província. Sua participação nas lutas garantiu o sucesso da causa da independência na região. Alguns dos líderes balaios, espalhados pelo Maranhão em 1939, foram heróis em 1822. Domingos da Silva, o Matroá, era um deles.

$\mathrm{O}$ episódio que deu origem à balaiada mistura mais uma vez esses dois mundos. Ou, se o leitor preferir, cruza esses dois níveis de conflito. A 13 de dezembro de 1838, na vila de Manga, o mestiço Raimundo Gomes, à frente de alguns homens, assaltou a cadeia pública para libertar seu irmão, preso por homicídio. Além do irmão, libertou outros presos que ali estavam por decisão de autoridades locais. A guarda da cadeia não reagiu. Ao contrário, aderiu ao assalto. Raimundo Gomes era vaqueiro em Arari, na fazenda do padre Inácio Mendes de Morais e Silva, do partido bentevi. Há duas versôes sobre seu caráter. A mais comum o apresenta como um criminoso cruel, outros dizem ter sido combatente do "Exército Auxiliador" cearense e um fugitivo das violências do barão da Parnaíba, presidente do Piauí. Um dado pouco lembrado é que antes de invadir a cadeia, Raimundo Gomes tentou resolver a questão pela via formal. O irmão havia sido preso de forma suspeita. Passava com outros vaqueiros por Manga, tangendo manadas do patrão para vender, quando oficiais militares interceptaram o grupo, levando alguns homens como recrutas e o irmão de Raimundo Gomes preso, sob acusação de assassinato. Este assistiu a tudo, mas conseguiu escapar. Inconformado, enviou ao subprefeito um requerimento, explicando o que considerava ser um mal-entendido e solicitando a libertação de seu irmão. $\mathrm{O}$ subprefeito, cabano, indeferiu o pedido. Só então, Raimundo Gomes decidiu pelo assalto. ${ }^{23}$

O sucesso da ação rendeu inúmeras adesões, transformando o episódio em movimento armado. Em pouco tempo, Raimundo Gomes tinha sob seu comando grupos de várias regiôes da província. As forças do governo organizavam colunas, perseguiam os rebeldes, mas tudo que con- 
seguiam era empurrá-los para o Piauí, o que só agravava o problema. Por onde passava, Raimundo Gomes deixava simpatizantes e recebia novas adesões. Do Piauí, retornou com cerca de 600 homens a mais.

Entre os líderes, não havia nenhum representante da elite local. Ninguém se envolvia de forma direta na rebelião. No entanto, o caos instituído, por desestabilizar o governo conservador, atraía inevitavelmente os liberais. O cerco e a ocupação de Caxias, segunda cidade da província em importância econômica, parecem ter sido facilitados pela oposição. $\mathrm{O}$ assunto é delicado. Essa associação entre liberais e rebeldes interessava aos conservadores. Inclusive aos da corte. Mas se essas alianças podem ser questionadas, por outro lado é inegável que, sobretudo no primeiro ano da revolta, liberais e rebeldes andaram bem próximos. Após a tomada de Caxias, os líderes do movimento criaram uma comissão militar para governar a cidade. Essa comissão, interessada em negociar um acordo de paz com o então presidente Manoel Felizardo de Souza e Melo, enviou uma deputação à capital. O grupo era composto de "homens ilustres", todos do partido bentevi. Meses depois, quando a rebelião se alastrou por toda parte oriental da província, devastando fazendas, interceptando a navegação dos principais rios e arrasando a população, todos negaram cumplicidade com os rebeldes, jurando que foram coagidos a integrar a deputação.

Grande parte dos proprietários e políticos locais parece só ter percebido os riscos dessa aproximação depois que Raimundo Gomes tomou toda a parte oriental do Maranhão, ameaçando a capital São Luís e ramificando-se pela margem piauiense do rio Parnaíba. Foi nessa ocasião que o movimento assumiu feição assustadora, com a devastação de fazendas e a adesão da população local. ${ }^{24}$

\section{A guerra é um meio de civilização}

O nível de civilização do Maranhão, para Gonçalves de Magalhães, explicava o que "à primeira vista d'olhos é inexplicável" - o "exército da rebeldia”. Para abordar o tema propóe pergunta: "O que se pode esperar de homens não domados por nenhum freio?” O editor do livro, um maranhense, incomodado com a descrição de Magalhães das "coisas e gente da terra”, ainda tentou, através de notas, relativizar suas críticas, lembrando que o autor vinha da Europa e, por isso, exagerava em seu julgamento. ${ }^{25}$ 
Em parte, ele tem razão. Magalhães escrevia a partir de um modelo civilizatório francês. Mas não eram as críticas em geral que afetavam o editor. $\mathrm{O}$ que produzia esse incômodo era um ponto preciso. $\mathrm{O}$ alvo do secretário poeta era a elite maranhense. Não porque parte dela teria se aproximado dos mestiços para definir disputas partidárias. A crítica não é dirigida aos liberais em especial. Para Magalhães, rebeldes e proprietários se encontravam no mesmo nível de civilização. Essa é a questão. "Senhores fazendeiros", eles próprios, não tinham "respeito às autoridades", e, sem considerar a lei, resolviam insultos por "suas mãos de particulares". Para tanto - prossegue o poeta - se valiam de "facínoras", davam-lhes abrigo e, por meio deles, se faziam "temíveis".

O Maranhão, na opinião de Magalhães, era uma sociedade de "brutos" e quem a fazia assim era a elite. Toda vez que um político ou proprietário recorria a um desses facínoras, estimulava as "rixas". Quando, levados pela preguiça, esses proprietários optavam por "tudo que é colher sem martirizar a terra", abdicando da lavoura e coalhando a província de "fazendas de gado vacum", criavam ainda "cardumes de homens ociosos, sem domicílio (...) pouco dados a outros misteres e muito à rapina e à caça, distinguindo-se dos selvagens apenas pelo uso de nossa linguagem”. Era preciso, orientava Magalhães, "historiar", "conhecer esses homens". Só isso possibilitaria uma ação eficaz na província. Também responsabilizava os proprietários pela proliferação de quilombos nas matas do Maranhão. Para ele, os escravos só tentavam "subtrair-se ao jugo do senhorio" porque eram tratados "com bárbaro rigor". Até o necessário sustento, esses senhores lhes negavam. "Essa é a gente", conclui, "que incitada nos faz a guerra."

Tudo isso foi ouvido com atenção por Luiz Alves. ${ }^{26}$ Sem discordar de que a guerra é uma calamidade, encerrou seu relatório de governo, em 1841, afirmando que ela também pode ser "um meio de civilização para o futuro". ${ }^{27}$ Essa idéia organizou toda sua atuação na província. A primeira incursão que realizou pelo interior, por vilas que tinham estado sob domínio rebelde, só ocorreu precisamente um mês depois de sua posse, no dia 7 de março. Até essa data, Luiz Alves permaneceu na capital, organizando a administração militar da província. ${ }^{28} \mathrm{~A}$ administração civil também passou por uma expressiva reorganização, mas esta ocorreu de forma mais lenta, ao longo do ano de 1840. Convertida em estratégia militar e política, essa ação 
administrativa se tornou um marco do governo Luiz Alves, evidenciando a sintonia existente entre o presidente e seu secretário. Se a questão era "domar” esses homens, como sugeria Gonçalves de Magalhães, a guerra dirigida pelo coronel Lima devia implantar mecanismos de controle mais duradouros naquelas terras - os "freios" de que falava seu secretário. Só assim ela poderia civilizar. Guerra e administração se uniam num ponto - na necessidade de se reconstruir a ordem naquele território do Império.

Parte dessa tarefa já tinha sido realizada pelos próprios rumos da rebelião. $\mathrm{O}$ desespero provocado pela falência econômica da província tinha se encarregado de dissolver a explosiva liga que misturava elite, mestiços e negros, iniciando o processo de reestruturação das antigas fronteiras sociais. Quando o coronel Luiz Alves de Lima chegou à província, encontrou seus habitantes mais abastados e influentes clamando contra esses "bandidos". Assim, precisava apenas consolidar essa fronteira social, que voltava a ser reconhecida por eles. Os rebeldes eram bandidos. À elite cabia, como ele costumava afirmar, cultivar "a paz, condição da riqueza e prosperidade dos povos" ${ }^{29}$

A imagem de "agente neutro", cultivada pelo presidente e coronel Lima desde sua primeira proclamação na província, fortalecia essa idéia. Ele estava ali, entre os maranhenses, não para defender tal ou qual partido, mas para mostrar a esses homens as vantagens da cultura civilizada que, em economia, era sinônimo de prosperidade. Não à toa, sua primeira intervenção na região procurava restituir a ordem econômica. Apenas cinco dias após sua posse, Luiz Alves baixou uma ordem para que "os comandantes dos pontos existentes nas margens desse rio [Itapicuru] mandem acompanhar por uma escolta até o ponto imediato, e assim por diante, todas as embarcações de comércio que transitarem pelo rio”. Esse foi o primeiro emprego que fez das forças militares. $\mathrm{Na}$ verdade, a estratégia tentava recuperar a navegação no rio, interceptada pelos rebeldes. A guerra civilizatória tinha obrigação de "dar uma segura proteção ao comércio desta capital". Além disso, ela reabria a melhor e mais barata via de acesso ao interior da província, por onde passariam mercadorias e, junto com elas, as tropas do governo. ${ }^{30}$

Para que essa estratégia atingisse seu objetivo, de capitalizar o apoio da elite, o presidente teria que passar para a administração de homens - 
de sua tropa. No dia 21 de fevereiro, baixava outra ordem. Exigia dos "senhores comandantes (...) o maior cuidado para que as forças legais não cometam excessos por onde transitarem" e destacava que era imprescindível "manter a disciplina militar e o respeito às propriedades". Mas a indisciplina não estava apenas nas tropas. Dias depois, o coronel determinava aos comandantes que não tomassem dos fazendeiros nenhum objeto para as tropas "sem que aos mesmos se entreguem recibos". Manter esses homens em ordem era um desafio tão grande que, dentre várias estratégias, o coronel Lima adotou uma particularmente curiosa: dispensou todos os feitores do serviço militar para que pudessem - explicou ao ministro - "defender as fazendas dos excessos de nossas tropas". ${ }^{31}$

O efetivo do governo, nessa fase inicial, ficava em torno de 5.000 homens, distribuídos em duas classes: uma de operações e outra de guarnição de fortalezas, vilas e cidades. Mas não devemos pensar em forças homogêneas, muitas nem existiam como unidades militares antes da guerra. O coronel Lima, ao chegar a São Luís, encontrou corpos militares que já estavam em operação na região (e, com isso, marcados por uma experiência desconhecida) e recebeu várias unidades de províncias próximas, como o Ceará, Pernambuco e Piauí. Ao coronel coube distribuir esses homens em corpos, construir uma relação de comando-obediência e, nesse sentido, costurar alguma unidade. Esse conjunto é que ficou conhecido como Divisão Pacificadora do Norte. ${ }^{32}$

A administração militar é que permitiria controlar esses homens, tão mais perigosos porque estavam armados. $\mathrm{O}$ controle devia começar pelos comandantes. Para que a ação funcionasse, eles deveriam, ao menos, obedecer ao governo. Todavia, só a persuasão não bastava. $\mathrm{O}$ controle tinha que ser mais rigoroso e, para isso, dependia da construção de uma rede técnico-burocrática. Todos esses comandantes tinham ampla liberdade para recrutar. Isso já era motivo para muita preocupação. Tradicionalmente, o recrutamento era uma arma política. Quem estava no governo recrutava na oposição ou, como o imposto era dirigido às classes populares, recrutavase pessoas diretamente vinculadas a chefes oposicionistas. Assim, ao mesmo tempo em que autorizava o recrutamento, Luiz Alves exigia o envio das "relaçôes" das praças recrutadas para o quartel do comando das armas "com todas as declaraçóes para que o quartel-mestre as rubrique e comunique ao 
sr. comissário pagador". Essas relações deviam ainda ser "assinadas pelos comandantes de companhia" e "rubricadas pelos das colunas". ${ }^{33}$

O cuidado prosseguia, e não era apenas com o recrutamento. Tendo este sido liberado, era preciso ter controle sobre o efetivo total, sobre o modo como ele estava distribuído e sobre as ordens passadas a esses homens. Desse modo, as relaçóes de recrutados, por exigência do coronel Lima, deveriam ser arquivadas em um livro, o mesmo ocorrendo com as ordens do dia, lançadas, todas, em um grande caderno. Cada comandante de corpo também era responsável por enviar o mapa da força dessa unidade - a menor de um Exército - ao comandante de guarnição e este, por sua vez, enviaria, mensalmente, esses mapas ao Comando de Armas da província. Para evitar os conflitos de autoridade, foi exigido, por fim, que os requerimentos, por mais simples que fossem, obedecessem aos trâmites da lei para subir à autoridade competente.

Essas providências logo surtiram o efeito esperado. No dia 6 de março, com apenas um mês de governo, Luiz Alves de Lima escrevia ao ministro da Guerra, informando que as margens do rio Itapicuru estavam guarnecidas, em toda sua extensão, por tropas legalistas e que as cidades de Caxias e Tutóia também estavam livres dos rebeldes. Com o avanço legalista, estes haviam fugido. A notícia era excelente. Às margens do rio Itapicuru estavam importantes fazendas de algodão da região.

O coronel Lima ganhava, com esses sucessos, o respeito e apoio de parte dos proprietários. Mas o trabalho de "pacificação" apenas se iniciava. Luiz Alves estimava que cerca de 3.000 rebeldes permaneciam em armas, concentrando-se, a maior parte, na comarca do Brejo, entre Tutóia e Morro Agudo, e na comarca de Pastos Bons. Além desses núcleos, havia um grupo de cerca de 600 negros aquilombados na mata próxima a Caxias. Em função disso, Luiz Alves comunicou ao ministro, nesse mesmo ofício, que as três colunas deixariam seus acampamentos e marchariam para Chapadinha, onde se achavam os chefes rebeldes Raimundo Gomes e Pedro Alexandrino. A idéia era cercá-los, atacando em várias frentes. Para aproveitar o impacto de toda essa movimentação de tropas, Luiz Alves decidiu que era hora de deixar a capital, começando sua incursão por Icatu, Rosário e Itapicuru-Mirim, vilas que, junto com o rio Mearim, formavam uma espécie de cinturão de proteção a São Luís. Além disso, esse 
era outro centro produtor de algodão. O presidente coronel Lima pretendia, como afirmou ao ministro, "animar a região" com sua presença, fazer "inspeçôes" e "melhoramentos convenientes". Estavam, contudo, em plena "estação invernosa", e o coronel não fazia idéia do quanto isso iria interferir em seu trabalho de esquadrinhamento territorial. ${ }^{34}$

A estação começava em dezembro e podia prosseguir até junho. Era uma época de chuvas copiosas e intermitentes, que transbordavam rios e espalhavam "pestes". ${ }^{35}$ Em maio, por exemplo, Luiz Alves desembarcou em Miritiba com 340 praças para explorar a regiāo. "Todo terreno estava inundado com as copiosas águas da estação pluviosa”, registrava o coronel. Em função disso, teve que alterar o rumo da exploração, dirigindose para a vila de Priá, menos atingida pelas chuvas. Um fato semelhante aconteceu com a expedição do capitão Joaquim Pereira Chaves. Após um ataque bem sucedido à vila de Ribeira, não pôde prosseguir no seu intento de bater os rebeldes. O motivo? Havia perdido todo cartuchame, inutilizado pelas águas. Com as chuvas, vinham ainda as febres intermitentes. Em janeiro, mês climático dos mais difíceis, o coronel Luiz Alves escrevia ao ministro dizendo que o hospital da capital "é por mim visitado quase diariamente". A peste, sobretudo no interior, fazia "imensos estragos". Em três meses, morreram mais de 1.000 crianças de sarampo e, em nove dias, um acampamento perdeu "do mesmo mal 111 apresentados".

O cuidado de visitar os hospitais, trabalho que ele vinha fazendo desde agosto, entre uma incursão militar e outra, não atendia apenas a interesses militares. Luiz Alves - vale lembrar - era também presidente da província. Devia zelar pelo atendimento médico de militares e civis. $\mathrm{O}$ quadro geral era dramático. Explicava ao ministro da Guerra, em ofício de agosto, que "a maior parte do Icatu era insalubre, onde um terço da população é vitimada pelas febres intermitentes, obstruções e feridas atônicas”.

Por entender que parte desses problemas era anterior à guerra, é que o secretário de Luiz Alves culpava a elite maranhense. O estado de abandono da economia, saúde e transportes, tanto quanto a própria rebelião, resultava de sua pouca disposição para o trabalho. O que dificultava a atuação da repressão era o "estado bruto" dessa sociedade. Seu governo devia, assim, assumir também uma função educativa. Devia ser um exemplo de intervenção eficaz na região e a prova de que, mesmo diante de tantas ad- 
versidades, era possível, através de um engajamento pessoal, exercer uma direção sobre os negócios da província. Por isso, o coronel Lima nunca desprezou o valor de sua presença nas vilas, comunicando ao ministro, como parte de sua estratégia, que viajaria para o interior com o objetivo de "animar a região". ${ }^{36}$ Nesse sentido, a presença de Luiz Alves era, ela mesma, uma intervenção, a primeira que realizava.

Depois da abertura das sessões legislativas, no dia 3 de maio, o presidente contou com o apoio irrestrito da Assembléia Provincial na aprovação de várias leis e, por conseguinte, na ampliação dessa ação administrativa. Quando se viu com essa vantagem política, iniciou a reforma de instituições educacionais e religiosas. O coronel Lima, talvez para satisfazer os interesses de seu "amigo leal" e secretário de governo, optou por dirigir sua atenção para instituições formadoras de valores. A intervenção, realizada no campo administrativo, tinha a clara intenção de criar os "freios" de que a província, na avaliação de Gonçalves de Magalhães, se ressentia, contribuindo, desse modo, para "domar" o território - os corpos e almas maranhenses.

Combates, intrigas e espias

Uma série de ataques ocorreram durante os meses de junho e julho. A força do tenente Sampaio, reunida à do alferes Chagas e ao destacamento de Morro Alegre, explorou as vilas de Salitre, Rodeio e Capivara, batendo grupos que "por ali roubavam capitaneados por Raimundo Gomes". No dia 7 de junho, uma outra força, comandada pelo capitão Castanhedes, sustentou "fogo desde as 7 horas da manhã até às 2 da tarde", perseguindo o grupo do temido chefe Tempestade. No dia 19, também de junho, o capitão Sampaio fez vivo fogo à "gente de Raimundo Gomes" e, no dia 15 de julho, uma força integrada por tropas do Ceará e do Piauí efetuou uma grande investida na margem piauiense do rio Parnaíba. Em todos esses confrontos, foram feitos prisioneiros, mortos e muito se contabilizou de cavalos, armas e salitre apreendidos. Ainda assim, malgrado todos os esforços, havia - é o coronel Lima quem o afirma - "grandes e numerosos magotes pelas matas, que espiam o menor descuido nosso e que procuram sublevar escravos das fazendas por onde passam". Essa última estratégia rebelde voltava a inquietar o coronel. Raimundo Gomes 
a adotava sempre que se via "acossado" ${ }^{37}$ Ele, a princípio, "não quis se ligar à escravatura”, mas agora complicava o governo, ensinando os negros a incendiarem as fazendas que abandonavam. Novas forças eram organizadas, explorações realizadas e, muitas vezes, as forças legais saíam desses combates com um saldo até bem positivo. No ataque ao forte do Bonfim, no dia 24 de junho, um líder rebelde, conhecido como Macambira, foi morto. No mês anterior, depois de um dia inteiro de combates, uma força legal conseguiu prender o chefe Aleixo Gomes Balaio, que logo em seguida, em virtude de seus ferimentos, morreu. ${ }^{38} \mathrm{Nada}$ disso, porém, animava o coronel Lima. Julho terminava sem avanços expressivos e, abatido, ele escrevia ao ministro da Marinha: "Notícias favoráveis têm se espalhado sem grande fundamento, porque o número de rebeldes não tem diminuído, ao contrário, depois do ataque (...) ao Piauí, dispersos, eles atravessaram o rio Parnaíba e vieram a incorporar-se aos desta província, os quais montam hoje a quatro mil." ${ }^{39}$

Para vencer essas dificuldades e desbaratar a rebelião, Luiz Alves decidiu recorrer a outro estratagema: lançar mão de espias para "despertar a antiga indisposição contra os negros" e "introduzir a cizânia entre os rebeldes". ${ }^{40}$

Uma representação dos rebeldes havia chegado até o coronel nos últimos dias de julho. Através de uma proclamação, ordenou "que depusessem armas". Meios brandos, "empregados com gravidade e sem quebra de força", poderiam, na opinião de Luiz Alves, "colher bons resultados". Tinha todo interesse em negociar uma rendição. Apesar de "destroçados e sem recursos", os rebeldes provocavam "grandes danos em suas contínuas correrias, incendiando e destruindo fazendas e embrenhando-se na mata de onde só saem para interceptar as estradas". No entanto, Raimundo Gomes e os "demais assinados" impuseram condições consideradas "inatendíveis" pelo coronel. Junto com a recusa, ele fez marchar uma força que a sustentasse. $\mathrm{O}$ chefe rebelde, por sua vez, respondeu que não estava em "estado de entregar as armas", informando que tinha sob suas ordens, naquele preciso momento, 2.000 homens. Era mais uma tentativa de negociação que fracassava. Luiz Alves, acreditando que o chefe rebelde contava, entre esses homens, com negros das margens do rio Itapicuru, mandou uma força "cair sobre o bando e dispersá-lo". No dia 3 de agosto, outra força bateu o exército de Raimundo Gomes. Quarenta homens, 
entre eles o irmão do chefe rebelde, Cândido do Lago, depuseram armas. Antônio Viana, bagageiro de Raimundo Gomes, em seguida também se entregou. Dias depois, quando Luiz Alves já estava no acampamento de Vargem Grande, mais 200 rebeldes se apresentaram. Com ânimo renovado, o coronel arriscava até uma previsão: "É provável que nesses três meses tudo esteja acabado." 41

Após a defecção de parte de sua tropa, Raimundo Gomes ofereceu seus serviços ao negro Cosme. Considerado por Luiz Alves uma "importante figura”, o negro gerava verdadeiro terror nos fazendeiros da província. Isso se devia não só à força crescente do grupo sob seu comando, mas à facilidade com que seduzia os escravos. Intitulando-se "Tutor e Imperador das liberdades", prometia alforria e chegou a criar até uma "escola de ler e escrever". O quilombo funcionava na fazenda da Lagoa Amarela. Pelo que consta, os negros teriam se apossado dela depois de obrigar o proprietário a assinar 200 "cartas de liberdade" antes de assassiná-lo. Negro Cosme, aproveitando a experiência de Raimundo Gomes, o empregou na fabricação de pólvora. Falava-se também em um projetado ataque da dupla a Manga, vila de origem da revolta. Mas esses fatos não deixavam mais Luiz Alves inquieto. Foi nesse mesmo ofício, aliás, que pela primeira vez previu o fim da guerra. Foi nele também que informou ao ministro sobre as espias, usadas para introduzir a cizânia entre os rebeldes. ${ }^{42}$

Uma vila visitada pelos espias do comandante foi Carnaubal. No dia 20 de agosto, Luiz Alves enviou para o local quatro espias. Através de carta reservada ao comandante militar da vila de Itapicuru-Mirim, major Oliveira, ordenava que o oficial pagasse a cada um deles 200 mil-réis e lembrava que não devia "exigir recibo para que não fiquem desconfiados". Tudo estava arranjado. Para a prestação de contas, o coronel Lima garantia ao major que bastava apresentar "esta minha ordem".

Ainda que não tenha sido possível identificar com precisão o serviço executado por essa "comissão", a atenção que Luiz Alves lhe dedicou foi total. Ele acompanhou de perto o trabalho dos espias e aguardou para conferir seus efeitos. A carta confidencial enviada ao major Oliveira é datada do dia 20 de agosto. No dia 22, o coronel se achava na "entrada de Carnaubal". O lugar estava "infestado de rebeldes" e, ao que tudo indica, o acesso a Carnaubal, interrompido. No dia 23, apenas três dias após 
o envio da carta, Luiz Alves deixava o local, comunicando ao ministro da Guerra que a estrada já estava "desembaraçada", que havia colocado ali forças para garantir seu "livre trânsito". ${ }^{43}$

O trabalho dos espias vinha surtindo efeito. Era essa a avaliação do coronel Lima sobre os resultados de uma outra comissão, anterior a essa. Numa carta, datada do dia 16, ele afirmava, satisfeito: "Tenho tido notícia pelos meus espias que a intriga que havia feito espalhar entre os rebeldes tinha feito o que eu desejava, isto é, que eles desconfiassem uns dos outros e se precipitassem a bater mutuamente." Mais tranqüilo, Luiz Alves pôde retornar ao acampamento de Vargem Grande. A despesa com essas comissões foi contabilizada na lista das "despesas secretas". Ao final da guerra, o montante desses gastos chegou a 4 contos de réis, o que equivalia à contratação de 20 espias. Através de um ofício dirigido ao ministro da Guerra, é possível ter uma idéia dos serviços financiados por essa despesa. A relação é apresentada pelo próprio coronel Lima, em ofício: ela permitiu "promover a apresentação dos chefes rebeldes Pedrosa, com 1.700 homens, e Cândido, com 200, recompensar emissários que disto se encarregavam, pagar espias e escravos que entre os outros espalhassem [notícias]".

Cruzando essas informações, é fácil entender o ânimo renovado de Luiz Alves no início do mês de setembro. Ele enfim tinha encontrado um meio eficaz de deter os rebeldes. $\mathrm{O}$ sucesso que obteve no desbaratamento das tropas de Raimundo Gomes, no dia 3 de agosto, também tinha sido resultado dessas "ações secretas". O "chefe Cândido" da relação de despesas de Luiz Alves é Cândido do Lago, irmão de Raimundo Gomes, que depôs armas após o confronto do dia 3, levando consigo 200 homens. A relação confirma que o contato com esses chefes ocorria através de emissários, e sugere que a rendição era remunerada. Mesmo sem dispor de documentos que definam valores, ou explicitem o pagamento, é quase certo que a negociação com os chefes rebeldes, tal como acontecia com os emissários, envolvesse dinheiro. Afinal, nenhuma outra forma de remuneração é apontada nos ofícios. Neles, a apresentação dos rebeldes sempre aparece como uma ação espontânea, expressão de arrependimento.

Francisco Ferreira Pedrosa - o outro chefe da relação de despesas, o "chefe Pedrosa" - foi mais um dos "apresentados" de agosto e se tornou o grande trunfo de Luiz Alves no combate aos negros. Em ofício ao minis- 
tro, o coronel afirmou que, "sabendo há mais de dois meses" do interesse do rebelde em se apresentar, e tendo notícia também de seu receio de não ser perdoado, decidiu a situação por um emissário. Fez saber ao chefe rebelde que "o governo o aceitava", mas impunha uma condição: "Que batesse os negros." Era esse o acordo. Primeiro, batia os negros. Depois, poderia depor armas. O serviço do emissário e a adesão de Pedrosa entraram na lista das "despesas secretas", que Luiz Alves garantia terem sido "de absoluta necessidade". Com elas - escrevia ao ministro - "poupei maiores quantias e sangue". ${ }^{44}$ Ele tinha toda razão. Essas negociações lhe permitiram, pela primeira vez, fazer uma previsão do tempo que levaria para concluir a "pacificação" e, quanto menos tempo durassem as lutas, menores seriam as baixas e as despesas. Mas a negociação, do modo como foi feita, também reforçou incrivelmente as fileiras legais e, o que é melhor, com mestiços da região. Francisco Pedrosa se apresentou com 1.700 homens, nada menos que um terço do total das forças imperiais. Todos esses homens ou haviam crescido, ou trabalhavam naquelas matas e campos, conhecendo muito bem a região.

Por isso, Luiz Alves parecia não se preocupar com a fuga de Raimundo Gomes para o quilombo do negro Cosme, nem com o suposto ataque da dupla à vila de Manga. Apoiado em suas estratégias secretas, o coronel já tinha projetado uma grande investida, em várias frentes, contra os negros. $\mathrm{O}$ ataque se deu em agosto. Após algumas horas de fogo, o sucesso foi incrível. Os negros debandaram "com prejuízo de onze mortos, 52 capturados, 4 mulheres, 4 crianças, 1 rebelde livre, 21 cavalos, 11 éguas, 19 cangalhas, 5 selas, algumas armas arruinadas, pólvora e chumbo". Batidos, eles procuravam, tal como os rebeldes, abrigo nas matas. A diferença é que agora Luiz Alves seria capaz de persegui-los. Aí estava o valor de seu novo aliado. Os negros que seguiram para Bela Água, região dominada por Pedrosa, foram com facilidade capturados. De início, foram 140 . Mas Pedrosa prosseguiu na perseguição. Pelo acordo, devia bater os negros até que se rendessem. A eficácia das estratégias do coronel Lima era indiscutível. Em fins de setembro, Raimundo Gomes ainda estava desaparecido, sem tentar novas investidas havia um mês, e o negro Cosme já tinha sido localizado, talvez pela ação de espias. ${ }^{45}$ 


\section{O Maranhão redesenhado}

No dia 23 de agosto, quando Luiz Alves avançava em sua negociações, a notícia da antecipação da maioridade de d. Pedro chegou ao Maranhão. $\mathrm{O}$ fato foi muito bem aproveitado pelo coronel, que, certamente com auxílio de seu secretário, mudava suas estratégias - armas e espias cediam lugar às estratégias discursivas. Luiz Alves, em uma proclamação, convertia um fato político - a maioridade - em marco de ruptura com o passado. A "nova época", ao devolver a governança ao imperador, abria ao Império uma fase de concórdia. À frente da nação, d. Pedro II se tornava "símbolo da paz, da união e da justiça”. Comparado a um pai, ele assumia a direção dos "destinos da grande família brasileira" para evitar o que vinha comprometendo seu Império: a guerra entre irmãos. ${ }^{46}$

Agora, as negociações avançariam com mais facilidade e tudo era uma questão de tempo. Os últimos a serem batidos foram Raimundo Gomes e o negro Cosme. Mas, para Luiz Alves, a pacificação estaria completa quando prendesse o mestiço. Cosme não era um rebelde, era um quilombola. A diferença pode parecer sutil, mas sua delimitação marcou a atuação do coronel na província. Rebeldes e negros pertenciam a mundos distintos. Logo, o tratamento não podia ser o mesmo. Em nenhum momento se dispôs a negociar com os negros. Eram escravos, não decidiam seus destinos. Também não cabia ao Estado puni-los. O papel de Luiz Alves, como representante da Coroa na região, era devolvê-los a seus donos - esse era um domínio exclusivo do poder privado. Raimundo Gomes, após ter sido preso, foi anistiado. Obrigado a assinar um termo de "evacuação da província” de oito anos, decidiu morar em São Paulo, o que não chegou a acontecer. Na viagem, o líder balaio foi assassinado. Cosme Bento das Chagas foi executado muito tempo depois, em setembro de 1842 . Nessa data, o então brigadeiro Luiz Alves de Lima estava distante do Maranhão. Combatia rebeldes de outra estirpe, paulistas e mineiros.

Afirmar que a política militar instituída pelo coronel Luiz Alves de Lima estava fundamentada em ideais civilizatório não implica negar sua filiação político-partidária. Tanto ele quanto Gonçalves de Magalhães defendiam os princípios conservadores de centralização política. $\mathrm{O}$ discurso civilizatório permitiu sustentar, entre os maranhenses, a imagem de "agen- 
te neutro" do governo. Mas é claro que a civilização pregada não era neutra. Ela representava a classe proprietária e, nesse sentido, lutava pela preservação de seus interesses. Não à toa, a primeira medida de Luiz Alves foi reabrir a navegação dos rios. Depois, autorizou a limpeza de vários rios menores, para que se tornassem navegáveis e distribuiu prêmios no valor de 800 mil-réis para os empresários que disponibilizassem mais de um barco para agilizar a navegação. Nesses serviços técnicos, que incluíam ainda o levantamento de mapas "mais cuidadosos" da província, o coronel Lima lançou mão dos engenheiros militares que integravam sua expedição. $\mathrm{O}$ resultado agradava enormemente aos proprietários e negociantes locais.

Por outro lado, todo esse trabalho evidenciava a incapacidade da elite local para exercer, sem influência do governo central, a direção da província. Esse é um outro aspecto desse esforço civilizatório e era assim que ele se vinculava aos princípios centralizadores. A civilização e suas luzes só poderiam alcançar as províncias e resgatá-las da barbárie através de uma intervenção do governo nacional - através da guerra, em situações limite, e por meio da administração, quando a vida seguisse seu curso normal.

É preciso observar ainda que o discurso civilizatório de Gonçalves de Magalhães não incluía temas modernos da política européia, como democracia e igualdade. A maneira como agiram em relação aos mestiços e negros mostra com clareza como esses ideais civilizatórios se erguiam a partir de uma visão hierarquizada da sociedade. Cada grupo receberia, durante a "pacificação", um tratamento compatível com sua posição social. Desse modo, ao mesmo tempo em que reprimia, o coronel Luiz Alves de Lima resgatava as fronteiras sociais dissolvidas pelo movimento e também produzia um novo espaço sóciopolítico - integrava o Maranhão ao projeto conservador de consolidação de um Império do Brasil.

\section{Notas}

${ }^{1}$ Esse artigo é uma versão de parte do capítulo 3 de minha tese de doutorado Caxias e a formação do Império brasileiro: um estudo sobre trajetória, configuração e ação política, defendida no Programa de Pós-Graduação em História Social da UFRJ em agosto de 2004. As duas grandes referências no debate sobre política imperial são: CARVALHO, José Murilo de. A construção da ordem. Teatro de Sombras. Rio de Janeiro: Editora da UFRJ, Relume-Dumará, 1996 e MATTOS, Ilmar Rohloff de. O tempo saquarema: a formação do Estado imperial. São Paulo: Hucitec, 1990. 
${ }^{2}$ MAGALHÃES, Domingos José Gonçalves de. A revolução na província do Maranhão desde 1839 a 1840. São Luís: Tipografia do Progresso, 1858.

${ }^{3}$ CARVALHO, José Murilo de. Op. cit., p. 231.

${ }^{4}$ MORAES, Antônio Carlos Robert. Território e História no Brasil. São Paulo: Editora Annablume, 2005, p. 46.

${ }^{5}$ Apud. CALDEIRA, Jorge (org.). Diogo Antônio Feijó. São Paulo: Editora 34, 1999, p. 93.

${ }^{6}$ MAGNOLI, Demétrio. O corpo da pátria. Imaginação geográfica e política externa no Brasil. São Paulo: Editora da Unesp / Editora Moderna, 1997, p.93.

${ }^{7}$ CARVALHO, José Murilo de. Op. cit., p. 23.

${ }^{8}$ CASTRO, Paulo Pereira. A experiência Republicana, 1831-1840. In: BUARQUE DE HOLANDA, Sérgio (org.). História geral da civilização brasileira, t. 2, vol. 2. São Paulo: Difusão Européia do Livro, 1967, p. 38.

${ }^{9}$ FLORY, Thomas. El juez de paz y el jurado en el Brasil imperial. México: Fondo de Cultura Económica, 1986, p. 85.

${ }^{10}$ CARVALHO, José Murilo de. Bernardo Pereira de Vasconcelos. São Paulo: Editora 34, 1999 , p. 19.

${ }^{11}$ FLORY, Thomas. Op. cit., p. 266.

${ }^{12}$ Relatório do Ministério da Justiça apresentado à Câmara dos Deputados em 1838.

${ }^{13}$ Correspondência do ministro da Justiça com o comandante geral do corpo, ofícios de fevereiro de 1838 - Arquivo Geral da Polícia Militar do Estado do Rio de Janeiro (AG PMERJ).

${ }^{14}$ Cartas a Monte Alverne de Porto Alegre e Gonçalves de Magalhães. São Paulo, Conselho Estadual de Cultura, 1964. Ver ainda um rascunho biográfico escrito por Manuel de Araújo Porto-Alegre. Lata 365, pasta 9 - Instituto Histórico e Geográfico Brasileiro.

${ }^{15}$ MAGALHÃES, Domingos José Gonçalves de. Op. cit., p. 45.

${ }^{16}$ SÜSSEKIND, Flora. O Brasil não é longe daqui. São Paulo: Companhia das Letras, 1990 , p. 16.

${ }^{17}$ ALENCASTRO, Luiz Felipe de. Memórias da Balaiada (introdução ao relato de Gonçalves de Magalhães). Novos Estudos Cebrap. São Paulo, no 23, março de 1989, p. 8.

${ }^{18}$ MAGALHÂES, Domingos José Gonçalves de. Op. cit.

${ }^{19}$ SERRA, Astolfo. Caxias e o seu governo civil na província do Maranhão. Rio de Janeiro: Biblioteca Militar, 1943, p. 49.

${ }^{20}$ A apresentação que se faz aqui da política maranhense segue o que há de consolidado na historiografia sobre o tema. Vale lembrar que a proposta do artigo não é discutir a Balaiada, mas sim as estratégias empregadas pelas forças imperiais a fim de inscrever o discurso da ordem no território do Maranhão.

${ }^{21}$ SANTOS, Maria Januária Vilela. A Balaiada e a insurreição de escravos no Maranhão. São Paulo: Editora Ática, 1983, p. 74. 
${ }^{22}$ Idem. P. 20.

${ }^{23}$ REIS, Arthur Ferreira. O Grão-Pará e o Maranhão. In: BUARQUE DE HOLANDA, Sérgio (org.). HGCB, t. 2, vol. 2. São Paulo: Difusão Européia do Livro, 1967, p. 159.

${ }^{24}$ SANTOS, Maria Januária Vilela. Op. cit., p. 29.

${ }^{25}$ As referências deste e dos dois próximos parágrafos foram extraídas do $2^{\circ}$ capítulo de MAGALHÂES, Domingos José Gonçalves de. Op. cit.

${ }^{26}$ Destacar o sucesso da parceria com Gonçalves de Magalhães não é o mesmo que afirmar que a política elaborada por ambos foi implantada de forma absolutamente racional e sem surpresas. Do Maranhão, há pouco mais de um mês de sua posse, o coronel Lima viveu momentos tensos. Ele e seu secretário ficaram praticamente isolados da corte. Os ofícios enviados ao regente, informando sobre a política adotada e perguntando se ela agradava ao governo, ficaram sem resposta. Voltaram a escrever no dia 17 de maio, dessa vez ao ministro da Guerra. No ofício o coronel dizia não saber "se a marcha militar e administrativa" estava "agradando ao governo." E, mais uma vez, não obteve resposta. Decidiram, então, arriscar. Essa noção do risco político presente em suas açōes ficará clara mais adiante, quando narro as estratégias e movimentações das tropas imperiais.

${ }^{27}$ Apud. SERRA, Astolfo. Op. cit. Anexos. p. 128.

${ }^{28}$ Para o tema da organização administrativa das forças da repressão e o da domesticação de seus oficiais, ver os ofícios ao ministro da guerra de 5 e 6 de março e as ordens do dia de 12, 14, 19, 21 e 26 de fevereiro de 1840. Coleção Caxias, caixa 808. Além disso, há um outro ofício de 5 de março, dirigido ao ministro do império, no códice 927 - volume 1. Tudo é do Arquivo Nacional (daqui por diante AN).

${ }^{29}$ Proclamação de Luiz Alves de Lima de 7 de fevereiro de 1840, caixa 808 da Coleção Caxias - AN.

${ }^{30}$ Ordem do dia de 12 de fevereiro de 1840. Coleção Caxias, caixa 808 - AN.

${ }^{31}$ Ofício de 5 março de 1840, ao ministro do Império. códice 927, volume 1 - AN.

32 O efetivo está no ofício de 6 março, a organização das tropas em ordem do dia de 19 fevereiro e o nome da divisão em ordem do dia fevereiro. Tudo de 1840 . Coleção Caxias, caixa $808-\mathrm{AN}$.

${ }^{33}$ Essas ordens e as do parágrafo abaixo estão nas ordens do dia de 12, 14 e 19 de fevereiro de 1840. Coleção Caxias, caixa 808 - AN.

${ }^{34}$ Sobre as condiçôes climáticas e o estado de abandono do Maranhão, ver: ofícios de 6 de março, $1^{\circ}$ e 28 de junho de 1840 e 8 de agosto de 1840, ao ministro da Guerra. Códice 927, volume I - AN. Há ainda, no mesmo códice, um ofício ao ministro do Império de 5 de janeiro de 1840 .

${ }^{35}$ MAGALHÃES, Domingos José Gonçalves de. Op. cit., p.15.

${ }^{36}$ Ofício de 6 março de 1840, ao ministro da Guerra. Coleção Caxias, caixa 808 - AN.

${ }^{37}$ Ofício de 21 jullho de 1840, ao ministro da guerra. Códice 927, volume 1 - AN.

${ }^{38}$ Ver ofícios de 8 agosto e 1o junho de 1840, ao ministro da Guerra. Códice 927, volume $1-\mathrm{AN}$. 
${ }^{39}$ Ofícios de $1^{\circ}$ junho e 21 jullho de 1840 , ao ministro da Guerra. Códice 927, volume 1 - AN

${ }^{40}$ Ofício de $1^{\circ}$ setembro de 1840 , ao ministro da Marinha. Códice 927, volume $1-$ AN.

${ }^{41}$ Ofício de $1^{\circ}$ de setembro de 1840 , ao ministro da Marinha. Códice 927, vol. 1 - AN.

${ }^{42}$ Para as estratégias secretas, os ofícios de 1 o de setembro de 1840 ao ministro da Marinha e outro da mesma data ao ministro da Guerra. Códice 927, vol. 1 - AN. Além desses, há o ofício de Feliciano Galvão, datado de agosto; o ofício reservado de 20 de agosto e o ofício de 5 de janeiro de 1841. Coleção Caxias, caixa 808 - AN.

${ }^{43}$ Ofício de $1^{\circ}$ de setembro de 1840 , ao ministro da Guerra. Códice 927, volume 1 - AN.

${ }^{44}$ Ofício de 5 de janeiro de 1841, ao ministro da Guerra. Coleção Caxias, caixa 808.

${ }^{45}$ Ofício de 23 de setembro de 1840, ao ministro da Guerra. Códice 927, volume 1-AN.

${ }^{46}$ Proclamação impressa datada de 27 de agosto 1840 . Coleção Caxias, caixa 808 - AN.

\section{Referência bibliográfica}

CALDEIRA, Jorge (org.). Diogo Antônio Feijó. São Paulo: Editora 34, 1999. CARVALHO, José Murilo de. A construção da ordem. Teatro de Sombras. Rio de Janeiro: Editora da UFRJ, Relume-Dumará, 1996.

. Bernardo Pereira de Vasconcelos. São Paulo: Editora 34, 1999.

CASTRO, Celso. A invenção do Exército brasileiro. Rio de Janeiro: Jorge Zahar Editor, 2002.

CASTRO, Paulo Pereira. A experiência Republicana, 1831-1840. In: BUARQUE DE HOLANDA, Sérgio (org.). História geral da civilização brasileira, t. 2, vol. 2. São Paulo: Difusão Européia do Livro, 1967, p. 9-67.

CARTAS a Monte Alverne de Porto Alegre e Gonçalves de Magalhães. São Paulo, Conselho Estadual de Cultura, 1964.

FOUCAULT, Michel. Microfisica do poder. Rio de Janeiro: Ediçōes Graal, 1979.

FLORY, Thomas. El juez de paz y el jurado en el Brasil imperial. México: Fondo de Cultura Económica, 1986.

GUIMARÃES, Manoel Luiz Salgado. Nação e civilização nos trópicos: o Instituto Histórico e Geográfico Brasileiro e o projeto de uma história nacional. Estudos Históricos. Rio de Janeiro, v. 1, n. 1, p. 4-27, 1988.

MAGALHĀES, Domingos José Gonçalves de. A revolução na província do Maranhão desde 1839 a 1840. São Luís: Tipografia do Progresso, 1858.

MATTOS, Ilmar Rohloff de. O tempo saquarema: a formação do Estado imperial. São Paulo: Hucitec, 1990. 
MAGNOLI, Demétrio. O corpo da pátria. Imaginação geográfica e política externa no Brasil. São Paulo: Editora da Unesp/ Editora Moderna, 1997.

MORAES, Antônio Carlos Robert. Território e História no Brasil. São Paulo, Editora Annablume, 2005.

NORDMAN, Daniel. Frontières de France. De l'espace au territoire. Paris: Éditions Gallimard, 1998.

OTÁVIO, Rodrigo. A Balaiada, 1839. Depoimento de um dos heróis do cerco a Caxias sobre a revolução dos "balaios". Rio de Janeiro: Imprensa Nacional, 1842. REIS, Arthur Ferreira. O Grão-Pará e o Maranhão. In: BUARQUE DE HOLANDA, Sérgio (org.). História geral da civilização brasileira, t. 2, vol. 2. São Paulo: Difusão Européia do Livro, 1967, p. 71-172.

SANTOS, Maria Januária Vilela. A Balaiada e a insurreição de escravos no Maranhão. São Paulo: Editora Ática, 1983.

SERRA, Astolfo. Caxias e o seu governo civil na província do Maranhão. Rio de Janeiro: Biblioteca Militar, 1943.

SOUZA, Adriana Barreto de. O exército na consolidação do Império: um estudo histórico sobre a política militar conservadora. Rio de Janeiro: Arquivo Nacional, 1999. - Caxias e a formação do Império brasileiro: um estudo sobre trajetória, configuração e ação política. Tese de doutorado apresentada ao Programa de Pós-graduação em História Social. Rio de Janeiro, 2004.

SÜSSEKIND, Flora. O Brasil não é longe daqui. São Paulo: Companhia das Letras, 1990.

VELHO, Gilberto; KUSCHNIR, Karina. Mediação, cultura e politica. Rio de Janeiro: Aeroplano, 2001. 


\section{RESUMO}

O objetivo desse artigo é descrever como se deu o processo de pacificação da Balaiada e, nesse sentido, mostrar como o discurso da ordem inscreveu-se no território do Maranhão. O conceito de território agrega processos próprios do campo da política. Ele envolve a relação de uma sociedade com um espaço determinado. Dai a idéia de cartografia da pacificação. Ao enviar tropas para o Maranhão, o governo criou redes de dominação e circuitos de exploração que garantiram a submissão desse território ao Império do Brasil.

Palavras-chave: Império, cartografia da pacificação, Balaiada e política conservadora.

\section{ABSTRACT}

This article intends to describe the process by which the revolt known as Balaiada was pacified and, doing so, to show how the "speech of order" was inscribed in the territory of Maranhão. The concept of territory aggregates processes that belong to the field of politics. It includes the relation of a society to a given space. From this notion comes the idea of a "cartography of pacification". By sending troops to Maranhão, the government created networks of domination and circuits of exploration that sustained the submission of this territory to the Brazilian Empire.

Keywords: empire, cartography of pacification, Balaiada, conservative policie.

Recebido em abril de 2008 e aprovado em junho de 2008 